\title{
Living in the riverbanks: \\ Case of the ogan malay community settlement, South Sumatera
}

\section{Bermukim di tepian sungai: \\ Kasus permukiman komunitas melayu ogan, Sumatera Selatan}

Zainal Arifin1, Fajri Rahman²

${ }^{1}$ Department of Anthropology, University of Andalas, Indonesia. E-mail: arifinzed@gmail.com

2 Department of Anthropology, University of Andalas, Indonesia. E-mail: nada2rahman@yahoo.com

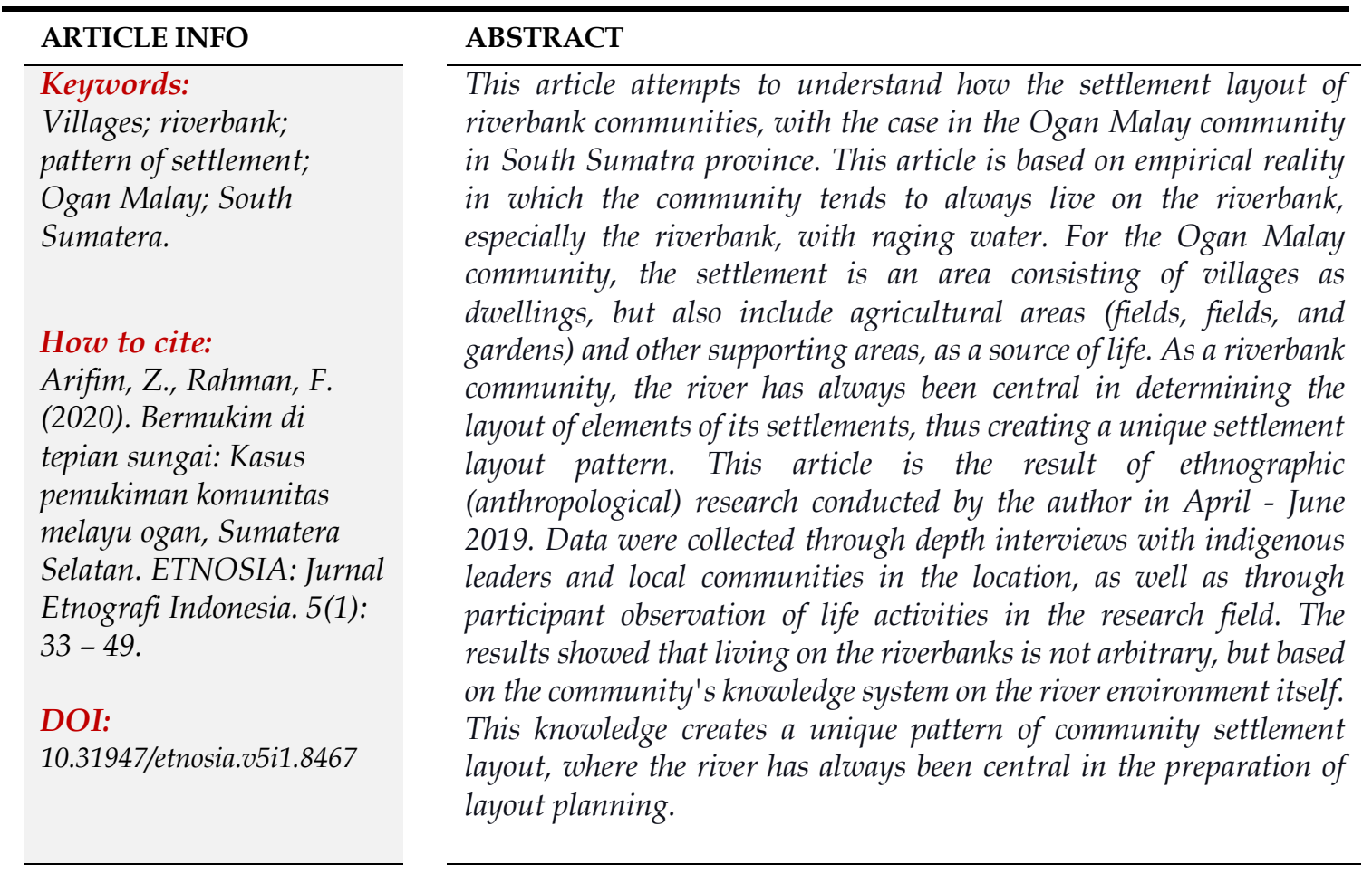

\section{Pendahuluan}

Gordon Wille mendefinisikan permukiman sebagai the way of which man disposed himself over the landscape on which he lived. It refers to dwellings, to their arrangements and to the nature and disposition of other buildings pertaining to community life (Ahimsa-Putra, 1997). Oleh sebab itu, menurut Winter, permukiman harus dibedakan antara pola permukiman (pattern of settlement) dengan permukiman sebagai sistem permukiman 
(settlement system). Apabila pola permukiman didefinisikan sebagai hubungan geografis dan fisiografi sekelompok situs kontemporer dalam satu budaya, maka sistem permukiman adalah hubungan fungsional antar situs yang terkandung dalam pola permukiman (Ahimsa-Putra, 1998). Ini menunjukkan bahwa sebuah permukiman tidak hanya sebagai tempat bermukiam, tetapi juga mencakup berbagai kegiatan budaya dan institusi sosial yang terdistribusi di atasnya, yang bersifat timbal balik (Kasmin, 2017).

Berangkat dari pemikiran di atas, maka permukiman dalam artikel ini lebih didefinisikan sebagai pengelompokan tempat tinggal oleh sekelompok manusia di suatu areal tertentu dengan segala aspek lingkungan alam dan sosial yang terkait dengan pengelompokan tersebut, sehingga dapat dibedakan dengan permukiman lainnya. Defenisi ini menunjukkan bahwa permukiman tidak hanya meliputi lokasi pengelompokan rumah sebagai tempat tinggal para pemukim saja, tetapi juga meliputi aspek-aspek lain yang terkait dengan pengelompokan tersebut seperti perladangan, persawahan, perkuburan, sungai, kelompok sosial serta aktifitas dan aturan-aturan yang diberlakukan oleh para pemukim di lokasi tersebut.

Memahami permukiman dalam perspektif budaya seperti ini, penting dilakukan karena sebuah permukiman tidaklah ditempatkan di lokasi tertentu secara suka-suka (arbitrer). Setiap komunitas cenderung memiliki sistem pengetahuan khas tentang pemilihan lokasi yang ideal dan lokasi yang dihindari sebagai areal permukiman, bahkan ketika permukiman sudah terbentuk, setiap komunitas juga memiliki cara khas bagaimana menata permukiman tersebut. Bermukim di tepian sungai, bisa dipandang sebagai ujud pola gagasan dan perilaku masyarakatnya (Ririmasse, 2007; Stahlberg, 2017). Dengan kata lain, sebuah permukiman lebih sebagai hasil pengejawantahan (ekspresi) konsepsi manusia mengenai ruang, serta hasil upayanya untuk mengubah dan memanfaatkan lingkungan fisik berdasarkan atas pandangan dan pengetahuan yang mereka miliki mengenai lingkungan tersebut (Ahimsa-Putra, 1997; Langub, 2016).

Selama ini kajian tentang permukiman tepian sungai memandang bahwa permukiman ada karena keberadaan sungai sebagai jalur transportasi. Hal ini misalnya dapat dilihat dalam beberapa kajian arkeologi seperti misalnya Susanto (2016), Intan (2016), dan Pahrudin (2010). Klaim ini tidak semuanya benar, karena banyak bukti menunjukkan bahwa beberapa permukiman tua yang ada di tepian sungai justru tidak selalu terkait dengan fungsi sungai sebagai sarana transprotasi. Prasetyo (2012) misalnya, menunjukkan bahwa situs arkeologi di sepanjang sungai Saling dan sungai Kikim yang ada di Lahat (Sumatera Selatan), keberadaannya lebih terkait dengan kebutuhan komunitasnya akan sumberdaya batu sebagai peralatan dalam kehidupan. Klaim ini tidak selamanya benar, karena kasus di komunitas Melayu Ogan justru berada di tepian sungai yang berair deras dan berbatu.

Kasus di komunitas Melayu Ogan ini membuktikan bahwa sungai memiliki nilai penting dalam budaya komunitasnya, Artinya, sungai bagi komunitas Melayu Ogan, tidak saja menjadi sumber bagi kehidupan mereka, tetapi juga adalah filosofi berkehidupan. Ini terlihat dari penamaan diri akan komunitasnya yang menggunakan nama sungai utama yang mengalir di lingkungan mereka, yaitu sungai Ogan. Penamaan diri akan komunitasnya dengan menggunaan nama sungai ini, sebenarnya juga terjadi di sebahagian besar komunitas Melayu yang ada di Sumatera Selatan. Bahkan 
penamaan wilayah administrasi pemerintahan pun relatif juga akan menggunakan nama sungai tersebut. Ini dibuktikan dengan penamaan 11 dari 17 kabupaten yang ada di provinsi Sumatera Selatan, justru diambil dari nama sungai utama yang mengalir di kabupaten tersebut.

Banyak bukti juga menunjukkan bahwa permukiman tepian sungai juga terkait dengan keberadaan sungai sebagai identitas yang perlu dijaga dan dipertahankan (Havrelock, 2007; Rice, 2007). Sebagai identitas, maka sungai juga sering menjadi sumber mitologi asal usul (Paine, 2018), pembentuk peradaban (Kumar, 2017), dan pemelihara peradaban itu sendiri (Ludvik, 2007). Ini membuktikan bahwa ada argumentasi budaya tertentu yang menempatkan sungai sebagai elemen penting dalam nilai budaya komunitasnya, sehingga melahirkan komunitas reverine culture (Hanafiah, 1985; Desfor, 2000). Artinya, bermukim di tepian sungai sangat dipengaruhi oleh kemampuan budaya komunitasnya dalam membaca lingkungannya. Oleh sebab itu, asumsinya tidak semua lokasi tepian sungai akan dijadikan lokasi bermukim, tetapi ada pemilahan-pemilahan tertentu berbasis pengetahuan budaya yang mereka miliki (Arifin, 1998; 2018).

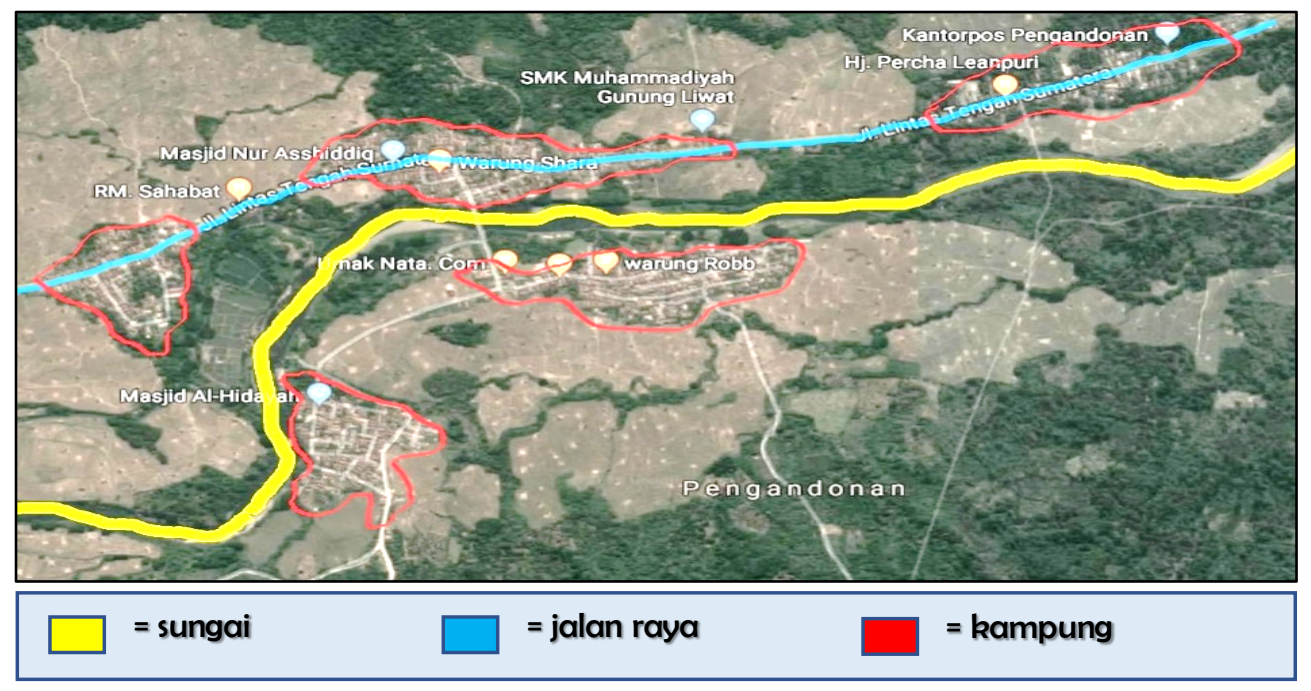

Gambar 1. Sebaran Beberapa Permukiman di Komunitas Melayu Ogan Sumber: https://www.google.com/maps/place/Pengandonan

Sistem pembacaan akan lingkungan ini pula yang membuat tidak semua ruang yang ada di lingkungan sungai akan menjadi lokasi bermukim. Ada pemilihan-pemilihan lokasi tertentu berbasis pengetahuan khas komunitasnya, sehingga melahirkan pola tata ruang khas permukiman tertentu. Pemikiran di atas, bermakna bahwa keputusan komunitas Melayu Ogan untuk bermukim di tepian sungai (apalagi sungai berair deras), tidaklah muncul begitu saja. Kemampuan komunitas Melayu Ogan dalam membaca dan menempatkan setiap elemen lingkungan sungai lah yang diasumsikan melahirkan pola tata ruang khas komunitasnya, sehingga dengan tata ruang yang demikian, diharapkan mampu tetap survive dari generasi ke generasi. Berangkat dari pemikiran ini, maka artikel ini mencoba memberi pemahaman tentang argumentasi budaya yang mendasari mengapa tata ruang pemukiman komunitas Melayu Ogan di Sumatera Selatan tersusun sedemikian rupa. 


\section{Metode}

Memahami argumentasi budaya (sistem pengetahuan lokal) mengapa pola tata ruang komunitas Melayu Ogan di Sumatera Selatan sedemikain rupa, tidak bisa dilepaskan dari cara pandang etnosains atau sering juga disebut sebagai cognitive anthropolagy. Cara pandang ini berangkat dari asumsi bahwa setiap komunitas mempunyai suatu sistem yang unik untuk mempersepsikan dan mengorganisasi fenomena materialnya (Peacock, 1970; Tyler, 1969). Pengorganisasian ini dilakukan dengan cara "menamai benda-benda" yang ada dalam lingkunganya dan mengorganisirnya ke dalam pengelompokan yang lebih luas dengan cara mengklasifikasikan dan menempatkan objek yang dihadapinya kedalam kategori-kategori yang sama (Wassmann, 2015; Boster, 2012). Berangkat dari pemikiran ini, maka sumber informasi utama terletak pada kekuatan informasi yang diberikan oleh para pelaku, dengan cara mengikuti pandangan atau makna yang diberikannya sebagai pendukung kebudayaan tersebut. Artinya interpretasi terhadap tindakan pelaku (penduduk asli) haruslah dilakukan sesuai dengan pola-pola penduduk asli itu sendiri (Keane, 2015).

Penelitian ini dilakukan di komunitas Melayu Ogan yang ada di kabupaten Ogan Komering Ulu (OKU) provinsi Sumatera Selatan, yang bermukim di sepanjang sungai Ogan. Secara sosial, kelompok yang bermukim di bagian hulu sungai Ogan sering menyebut dirinya sebagai uhang Uluan (orang Ogan bagian ulu), sementara yang bermukim di hilir sungai Ogan sering menyebut dirinya sebagai uhang Iliran (orang Ogan bagian hilir). Penelitian ini sendiri memfokuskan diri pada komunitas Melayu Ogan di bagian hulu (uhang Uluan), khususnya yang berdiam di 4 kecamatan yaitu kecamatan Ulu Ogan, Muara jaya, Pengandonan dan Semidang Aji. Alasan pemilihan lokasi ini, dikarenakan 4 kecamatan ini adalah lokasi utama komunitas uhang Uluan, sementara kecamatan lain di kabupaten OKU cenderung menjadi areal percampuran antar komunitas yang berbeda budaya. Pengumpulan data dilakukan dengan menggunakan wawancara mendalam dan observasi partisipasi. Wawancara mendalam (indepth interview) dilakukan kepada tokoh adat dan masyarakat umum yang ada di lokasi penelitian, yang digunakan untuk mendalami argumentasi budaya mengapa tata ruang pemukiman mereka sedemikian rupa. Sementara observasi partisipasi digunakan untuk mendalami bagaimana aplikasi argumentasi budaya para aktor tersebut tentang tata ruang permukiman yang mereka miliki.

\section{Hasil penelitian dan pembahasan}

\section{- Melayu ogan dan sebaran etnis di Provinsi Sumatera Selatan}

Provinsi Sumatera Selatan terdiri dari 13 kabupaten dan 4 kota, dimana pengelompokan masyarakat di provinsi ini relatif sangat variatif, yang menurut Melalatoa (1995) ada sekitar 23 kelompok etnis dan sub-etnis. Walaupun demikian, secara budaya, variasi kesukubangsaan ini tidak lah terlalu menyolok, dan bisa ditarik dalam akar budaya yang relatif sama, yaitu budaya Melayu Sumatera Selatan. Kesamaan budaya ini semakin diperkuat, ketika "kolonisasi" kesultanan Palembang yang tersebar sampai ke provinsi Lampung dan Bengkulu, menerapkan sistem pemerintah marga dengan undang-undang Simbur Cahaya sebagai pegangan utama masyarakat dalam berkehidupan. 
Intervensi kesultanan Palembang dengan sistem pemerintahan Marga ini, disatu sisi telah menyatukan masyarakat Sumatera Selatan menjadi sebuah kesatuan budaya, yang dalam beberapa literatur akhirnya dikenal sebagai budaya Melayu Sumatera Selatan. Namun disisi lain intervensi ini telah membuat munculnya varian budaya di beberapa komunitas tertentu, seperti rumah adat yang berbeda di setiap komunitasnya. Varian ini tidak saja terlihat dalam budaya benda, tetapi juga dalam budaya tak benda. Oleh sebab itu, memahami budaya masyarakat di Sumatera Selatan tidak bisa dilepaskan dengan budaya lokal yang sudah terintervensi oleh sistem pemerintahan marga tersebut (Arifin, 2015).

Secara administratif, Provinsi Sumatera Selatan memiliki dua pusat budaya besar, yaitu Palembang dan Besemah (Pasemah). Apabila Palembang menjadi pusat budaya Sumatera Selatan di bagian timur dengan tipe budaya maritim, maka Besemah menjadi pusat budaya di bagian barat dengan tipe budaya pedalaman. Dua pusat budaya ini memiliki karakter dan psikologi budaya yang berbeda, dimana budaya Palembang lebih mengembangkan kebiasaan yang mendasari kehidupannya dari maritim (perdagangan), sedangkan budaya Besemah lebih mengembangkan dan mendasari kehidupannya dari budaya hutan (pertanian). Sebahagian besar budaya masyarakat Sumatera Selatan di bagian timur cenderung banyak dipengaruhi oleh kelompok budaya Palembang, sedangkan masyarakat Sumatera Selatan di bagian barat (pedalaman) cenderung banyak dipengaruhi oleh kelompok budaya Besemah.

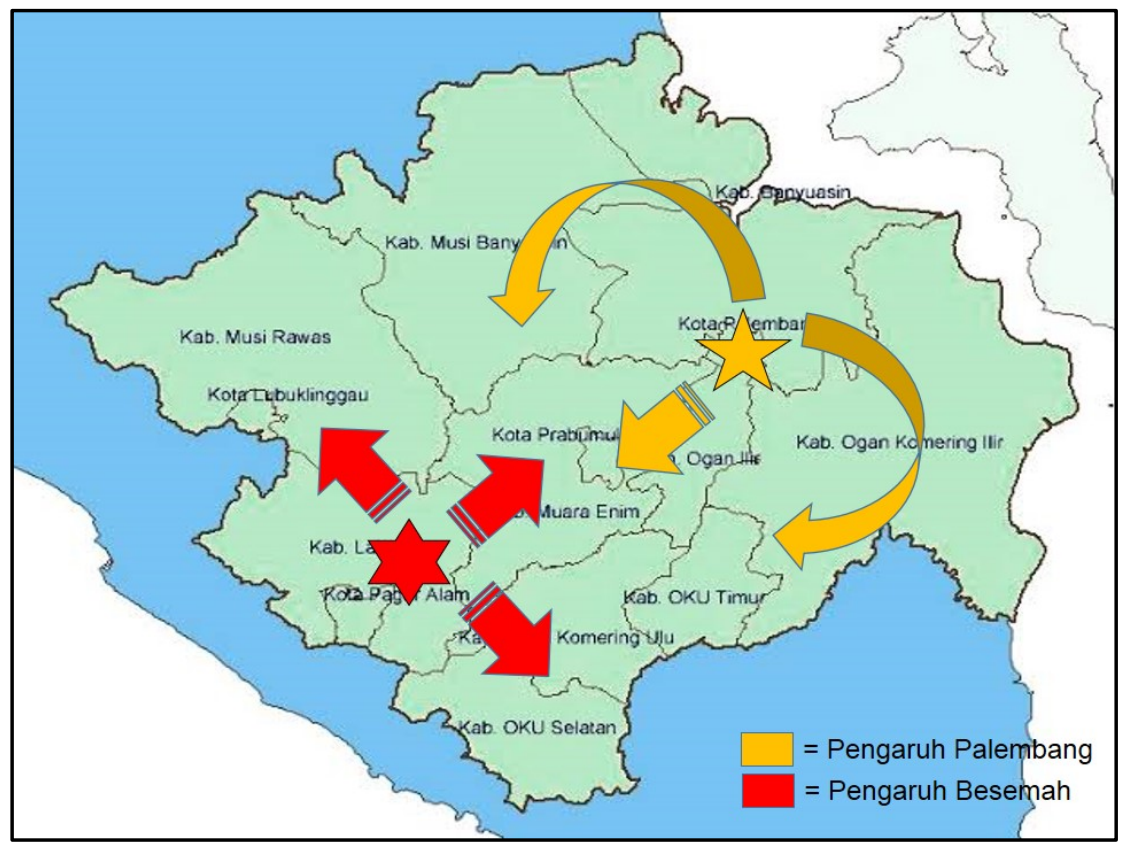

Gambar 2. Proses Pembentukan Sub-Etnik Melayu di Sumatera Selatan Sumber: hasil diolah penelitian

Palembang sebagai wilayah bagian timur yang begitu terbuka dengan dunia luar, akhirnya berkembang menjadi masyarakat aristokrat yang berpemerintahan (kerajaan). Sistem kerajaan ini lah yang akhirnya menyebar dan dikembangkan ke berbagai wilayah lainnya di Sumatera bagian Selatan. Berbeda dengan masyarakat pedalaman dengan pusat budayanya di Besemah, justru menjadi masyarakat yang egalitarian, yang 
menguatkan identitas dirinya melalui adat istiadatnya yang cenderung tanpa pemerintahan formal. Akan tetapi pada perkembangan kemudian, dengan kuatnya pengaruh dan intervensi kesultanan Palembang, akhirnya di masyarakat pedalaman ini disamping tetap menguatnya sistem adat lokal, disisi lain juga melahirkan pola kepemimpinan bersifat aristokrat.

Ogan adalah salah satu sub-etnik Melayu yang ada di Provinsi Sumatera Selatan, yang secara budaya adalah salah satu pecahan dari budaya Besemah yang mendapat pengaruh dari kesultanan Palembang. Untuk penyebutan dirinya, komunitas Melayu Ogan sering menggunakan kata uhang Ogan. Uhang yang berarti "orang", tidak saja merujuk pada siapa diri seseorang, tetapi secara komunal juga merujuk pada sekumpulan orang yang dianggap memiliki kebiasaan (budaya) dan identitas yang relatif sama. Identitas utama yang sering dijadikan acuan bagi komunitas Melayu Ogan untuk mengatakan dirinya uhang, adalah daerah asal usulnya, sehingga pertanyaan uhang mane ngan ni (anda orang mana), akan selalu mengacu pada daerah asal usulnya. Oleh sebab itu, secara lebih sempit, daerah asal usul ini adalah perkampungan asalnya, tetapi secara luas mengacu pada kesatuan komunalnya, yaitu Melayu Ogan.

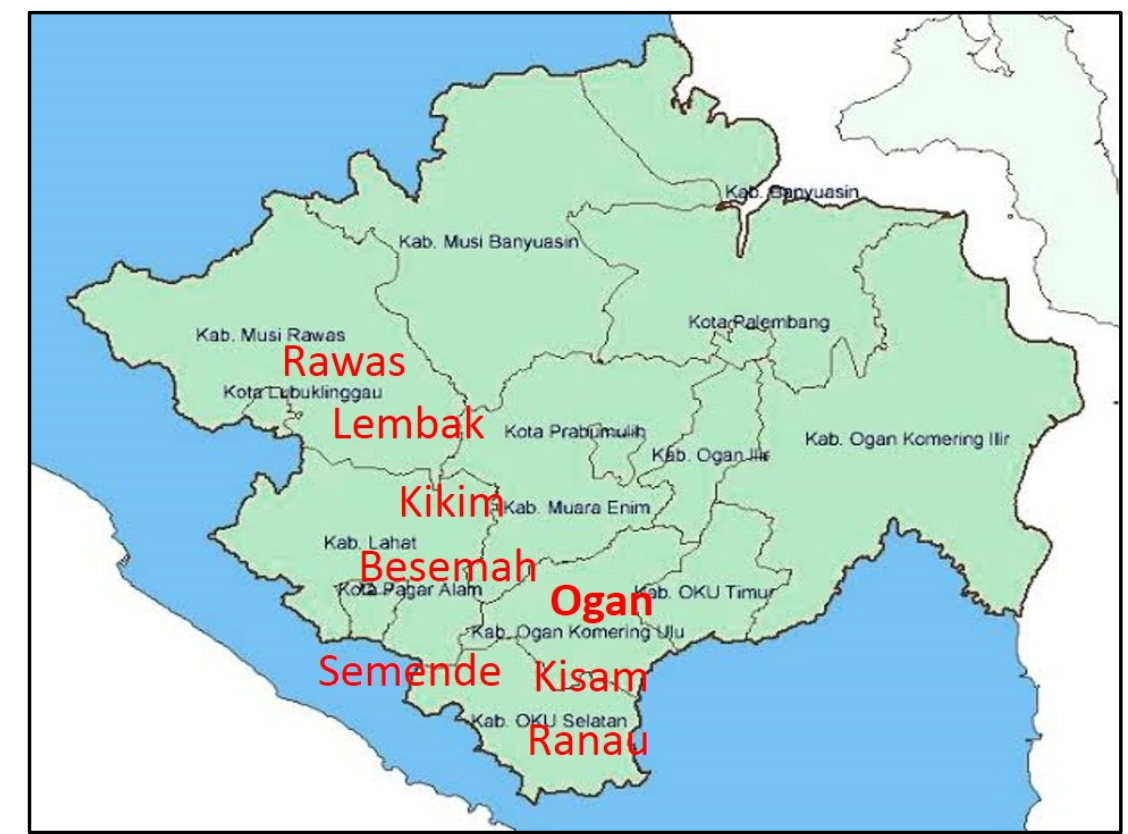

Gambar 3. Sebaran Etnik yang ada di Bagian Barat Provinsi Sumatera Selatan Sumber : diolah dari http://loketpeta.pu.go.id

Berangkat dari kesatuan komunal yang melekat pada uhang Ogan ini lah, oleh para ahli kemudian menempatkan Melayu Ogan sebagai salah satu etnik yang ada di Sumatera Selatan. Hal ini bisa ditemukan dalam buku Ensiklopedi Etnik di Indonesia (Melalatoa, 2015), yang menempatkan komunitas Melayu Ogan sebagai salah satu etnik yang ada di provinsi Sumatera Selatan. Istilah etnik ini sebenarnya tidaklah kaku, karena pada beberapa kasus kesamaan mitologi menjadi bagian penting dalam mengidentifkasi etnik. Akan tetapi sangat memungkinkan sebuah etnik akan terdiri dari berbagai kelompok dengan variasi kebudayaan yang berbeda, tetapi masih dapat dirunut pada satu induk, yang kemudian sering disebut sebagai sub etnik (ethnic group) (Melalatoa, 
2015). Mengikuti konsepsi di atas, maka uhang dalam terminologi komunitas Melayu Ogan, bisa dipahami sebagai sebagai ethnic group, karena setiap kelompok yang ada pada komunitas Melayu Ogan ini cenderung memiliki variasi budaya dan tradisi yang berbeda.

Secara etnik, Melayu Ogan adalah sebutan untuk komunitas yang berdiam di sepanjang sungai Ogan, yang berhulu di bukit barisan yang ada di di bagian barat Kabupaten OKU dan mengalir ke hilir sampai ke kebupaten Ogan Ilir, sampai akhirnya bertemu dengan sungai Musi. Pada perkembangannya, komunitas yang menempati bagian hulu sungai Ogan akhirnya lebih menyebut dirinya sebagai uhang Uluan. Sementara komunitas yang berdiam di hilir sungai Ogan menyebut dirinya sebagai uhang Iliran. Secara administratif. Uhang Uluan, mendiami sebagaian besar daerah di Kabupaten OKU, khususnya bagian utara dan timur kabupaten OKU, sampai ke wilayah Muara Kuang (kabupaten Ogan Ilir). Sementara uhang Ogan Ilir adalah komunitas yang mendiami sebahagian besar daerah yang ada di kabupaten Ogan Ilir. ${ }^{1}$

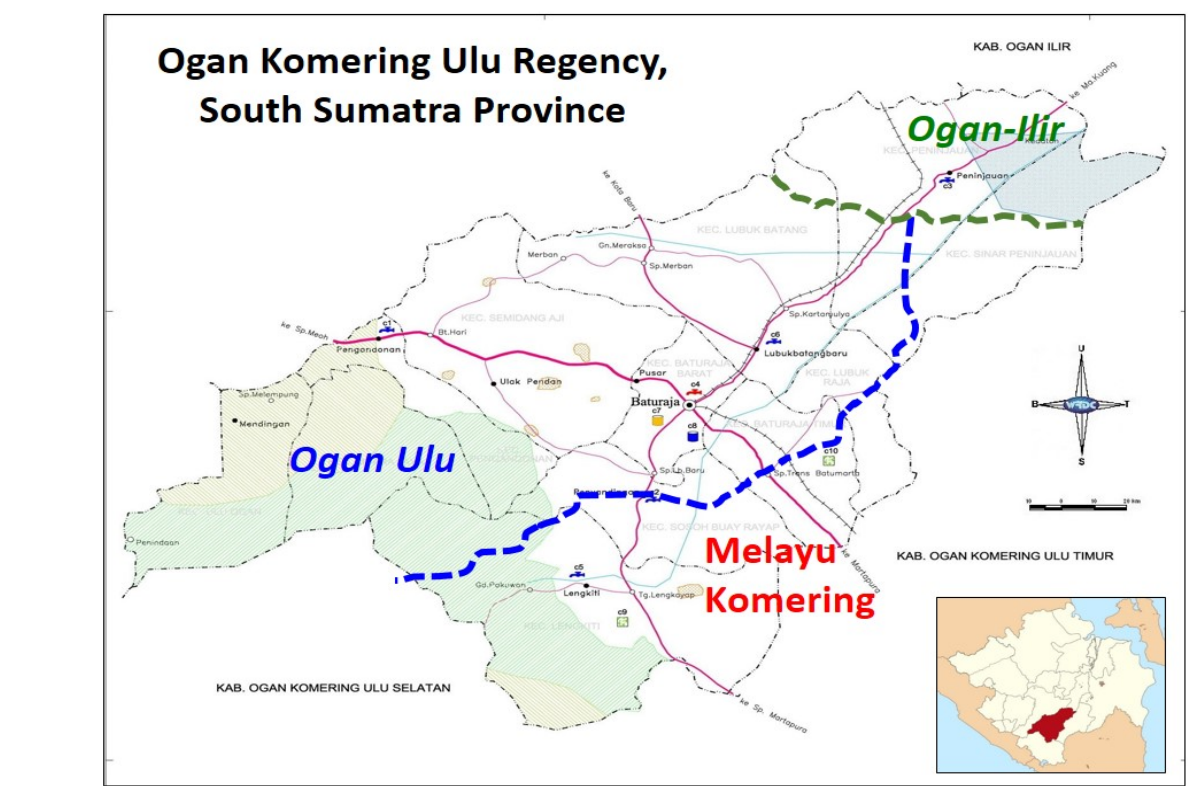

Gambar 4. Sebaran Melayu Ogan di Kabupaten OKU, Provinsi Sumatera Selatan Sumber: diolah dari http://loketpeta.pu.go.id

Sebagai komunitas yang terbuka dengan komunitas luar, maka di wilayah komunitas Melayu Ogan juga akan ditemukan komunitas dari berbagai etnik, seperti Minangkabau, Batak, Jawa, Sunda, Banten bahkan Bali. Kedatangan komunitas Minangkabau dan Batak bermula dari proses perdagangan, sedangkan komunitas Jawa, Sunda dan Banten, awalnya sebagai pekerja musiman dan pertukangan, yang lama kelamaan menetap dan berbaur dengan komunitas Melayu Ogan. Sementara komunitas Bali dan sebahagian komunitas Jawa masuk dan berbaur dengan komunitas Melayu Ogan melalui program transmigrasi. Setiap komunitas ini akan membawa tradisi dan budayanya masing-masing, tetapi dalam perkembangannya akhirnya mulai berbaur

\footnotetext{
${ }^{1}$ Walaupun ada penyebutan secara berbeda antar kelompok dalam komunitas Melayu Ogan ini, tetapi untuk memudahkan pembahaasan, maka komunitas uhang Uluan yang menjadi bahasan utama dalam artikel ini, ada disebut dengan istilah umum saja yaitu Melayu Ogan.
} 
dengan menggunakan tradisi dan budaya lokal. Walaupun komunitas Melayu Ogan adalah pemeluk agama Islam yang taat, tetapi cukup terbuka dengan keberadaan agama lain seperti Kristen dan Hindu yang dianut komunitas pendatang.

Berangkat dari data kependudukan tahun 2018, jumlah penduduk kabupaten Ogan Komering Ulu (OKU) adalah 359.092 jiwa. Dari jumlah ini diperkirakan penduduk komunitas Melayu Ogan berjumlah sekitar 349.824 jiwa. Jumlah ini didasarkan pada jumlah penduduk kabupaten OKU (diluar kecamatan Lengkiti yang dianggap sebagai wilayah komunitas Komering) dan ditambah dengan jumlah penduduk kecamatan Muara Kuang yang ada di Kabupaten Ogan Ilir. ${ }^{2}$ Komunitas Melayu Ogan adalah komunitas petani, dengan konsentrasi utama pada pertanian ladang dan sawah, dan hanya sebagian kecil yang hidup sebagai pegawai kantoran di berbagai lembaga pemerintahan dan swasta. Areal sawah cenderung selalu berada di tepian sungai dan dekat dengan perkampungan, sementara areal ladang berada di lapisan luar permukiman mereka, sehingga relatif menjauhi areal perkampungan.

\section{- Permukiman dan sistem pertanian}

Mata pencaharian utama komunitas Melayu Ogan adalah pertanian, khususnya perladangan dan pertanian sawah. Perladangan adalah mata pencaharian utama bagi komunitasnya, yang umumnya dilakukan di lahan perbukitan yang ada di sekitar permukiman. Adapun tanaman utama perladangan adalah kopi (Coffea arabica) dan karet (Hevea brasiliensis). ${ }^{3}$ Walaupun demikian, pada setiap awal pembukaan lahan perladangan, akan selalu diorientasikan untuk menaman jenis padi ladang (Oryza spp.). Hal ini disebabkan karena beras yang dihasilkan dari padi adalah sumber makanan pokok yang harus selalu disediakan dalam setiap keluarga. Oleh sebab itu, bagi anggota komunitas yang tidak memiliki lahan sawah, akan selalu menanam padi terlebih dahulu pada setiap awal pembukaan sebelum ditanami jenis tanaman ladang.

Beras, bagi komunitas Melayu Ogan bukanlah hasil pertanian yang akan diperjual belikan, seperti halnya hasil pertanian kopi dan karet. Ini disebabkan karena beras tidak saja dibutuhkan sebagai makanan pokok harian, tetapi juga penting sebagai basis sosial dalam kehidupan bermasyarakat. Hal ini disebakan karena beras juga digunakan oleh komunitas Melayu Ogan sebagai pemberian (pembawaan) ketika mengunjungi tetangga yang sedang melakukan upacara (sedekah). Oleh sebab itu, hasil produksi beras yang melimpah cenderung hanya akan disimpan sebagai persediaan untuk upacara dan kegiatan sosial lainnya. Seorang informan di lapangan mencoba menggambarkan akan arti pentingnya beras sebagai basis sosial dengan konsep malu.

"malu lah kita kalau pergi ke rumah tetangga yang lagi sedekah (upacara) tidak membawa beras. Lebih malu lagi kalau kita nya yang mau sedekah, tapi justru beli beras ke pasar. Kesannya kita tidak punya persiapan kalau mau sedekah (upacara)."

\footnotetext{
${ }^{2}$ Menurut BPS Kabupaten Ogan Ilir (2019), penduduk di kecamatan Muara Kuang, Kabupaten Ogan Ilir berjumlah sekitar 18.844 jiwa.

${ }^{3}$ Tidak ada catatan pasti, kapan komunitas Melayu Ogan ini mengembangkan perladangan mereka dengan tanaman kopi dan karet tersebut. Tetapi pada akhir abad ke-18, telah terjadi perambahan besar-besaran terhadap wilayah pegunungan Bukit Barisan di barat Provinsi Sumatera Selatan, sebagai akibat perluasan perkebunan kopi yang dilakukan komunitasnya (Guillaud, 2006).
} 
Malu dalam konsep komunitas Melayu Ogan terkait dengan persoalan harga diri (pride), sehingga ketiadaan beras akan dianggap merusak martabat dan kehormatan diri dan keluargannya (dignity and honor). Begitu pentingnya beras sebagai basis sosial komunitasnya, membuat kebutuhan akan beras menjadi orientasi utama dalam kehidupan komunitasnya. Beras sebagai tujuan pokok dalam mengembangkan kehidupan komunitasnya, membuat kemajuan sebuah kampung terkadang akan diukur dari sejauhmana komunitasnya mampu mengembangkan alternatif pertanian yang mampu menghasilkan beras secara melimpah.

Bagi komunitas Melayu Ogan, beras bisa dihasilkan di areal perladangan, akan tetapi sistem pengetahuan komunitasnya memandang bahwa kesuburan lahan perladangan akan tetap terjaga karena keberadaan tanaman keras yang tumbuh diatasnya. Untuk itu, ladang lebih dipahami sebagai lahan untuk pertanian dengan jenis tanaman keras seperti kopi dan karet. Sementara jenis tanaman padi lebih dipahami sebagai jenis tanaman rumput yang dianggap akan merusak kesuburan lahan perladangan apabila terus menerus ditanam di lahan ladang tersebut. Pengetahuan komunita Melayu Ogan lebih memandang bahwa tanaman padi lebih cocok tumbuh di areal yang cenderung basah yang dalam pengetahuan komunitasnya disebut tanah lebak. ${ }^{4}$ Pengetahuan akan fungsi lahan seperti ini membuat areal ladang dianggap bukanlah areal ideal untuk mengembangkan tanaman padi. Oleh sebab itu, kebiasaan menanam padi di areal perladangan, cenderung hanya dilakukan oleh komunitas Melayu Ogan sebagai bentuk pemenuhan kebutuhan sebelum dan selama proses perladangan berlangsung.

Pengetahuan akan fungsi lahan yang demikian, membuat orientasi utama untuk menanam padi cenderung akan dilakukan di lahan dataran rendah, dalam bentuk areal persawahan. Upaya menemukan lahan dataran rendah sebagai areal persawahan ini, membuat sungai selalu jadi orientasi utama bagi komunitasnya apabila ingin mengembangkan permukiman. Tepian sungai dianggap ideal sebagai lahan persawahan, tidak saja karena tipikal lahannya yang dianggap basah, tetapi juga dianggap akan lebih mudah memasukkan air ke lahan sawah apabila dibutuhkan. Hal ini penting, karena menurut komunitas Melayu Ogan, padi sangat membutuhkan air di awal pertumbuhannya, dan sebaliknya lahan perlu selalu basah (tapi tidak tergenang air) saat padi tersebut mulai menunjukkan bulir padinya.

Pengetahuan akan jenis tanaman padi ini lah yang membuat komunitas Melayu Ogan selalu berusaha menempatkan areal persawahan di dekat sungai. Sungai sebagai sumber air yang dibutuhkan akan dilakukan dengan cara membendung salah satu bagian tepian sungai agar air bisa dialirkan ke petak sawah tersebut. Strategi membendung aliran sungai ini, akan sulit dilakukan apabila aliran sungai yang ada cenderung beraliran tenang, sehingga bermukim di tepian sungai berair deras selalu menjadi impian bagi komunitasnya. Pengetahuan komunitas Melayu Ogan juga menempatkan bahwa padi selalu membutuhkan perawatan, sehingga seorang petani selalu berusaha bertempat tinggal di dekat areal persawahannya. Oleh sebab itu, sebuah

\footnotetext{
4 Tanah lebak (tanah basah) adalah istilah untuk menyebut jenis tanah yang cenderung berair karena posisinya di daerah kerendahan, tetapi bukan berbentuk rawa-rawa. Oleh sebab itu, tanah lebak juga sering digunakan untuk menyebut jenis tanah gunung yang ada di dataran rendah, khususnya yang ada di sepanjang aliran sungai.
} 
perkampungan akan selalu berada di dekat areal persawahan, dan ini juga yang menjadi alasan mengapa banyak perkampungan komunitas Melayu Ogan selalu berada di sepanjang aliran sungai yang ada.

\section{- Tata ruang dan pola permukiman}

Sungai sebagai kebutuhan utama akan air bagi setiap petak sawah, menjadikan komunitas Melayu Ogan selalu berorientasi menempatkan permukimannya di tepian sungai. Akan tetapi pada banyak kasus tidak semua areal tepian sungai akan menjadi areal persawahan, apalagi areal perkampungan. Hal ini disebabkan karena kelokan sungai akan selalu jadi pertimbangan utama dalam menentukan lokasi pengembangan sebuah permukiman. Pengetahuan komunitas Melayu Ogan, menempatkan bahwa kelokan sungai berair deras juga berpotensi merusak tebing sungai, yang diungkapkan diungkapkan dengan istilah nyapsap, yaitu aktivitas arus sungai yang mengikis bagian bawah tebing sungai. Akibatnya tebing sungai akan mengalami amblas, sehingga kondisi ini dianggap sangat berbahaya bagi kelangsungan areal persawahan tersebut, bahkan akan merusak perkampungan mereka di kemudian hari.

Oleh sebab itu, lahan sawah dan perkampungan cenderung tidak akan ditempatkan secara langsung di depan kelokan sungai. Apabila areal sawah akan ditempatkan di bagian hilir kelokan sungai, maka areal perkampungan justru akan ditempatkan di bagian hulu kelokan sungai. Seorang informan mencoba menceritakan pengalamannya saat banjir bandang melanda kampung mereka tahun 1982 yang silam.

“waktu mau banjir itu (tahun 1982), tanah tepi (sungai) Ogan itu bergerak seperti ada yang menjalankan ke arah kampung ini, jadi tidak kelihatan kalau ada arus di bawah tanah itu. Orang dulu nyebutnya nyapsap, jadi air deras itu menusuk ke tanah yang ada di bagian bawah tepian tebing, makanya tanah itu akan longsor secara perlahan. Akhirnya waktu itu banyak sawah di kampung kami yang rusak, kami dulu kampung tidak terkena aliran nyapsap itu, karena kampung agak menjauh dari tepian Ogan itu."

Apa yang diceritakan informan di atas, menunjukkan bahwa nenek moyang (puyang) pendiri sebuah kampung, memilih lokasi perkampungan yang jauh dari kelokan sungai, bukanlah tanpa alasan. Sistem pengetahuan tentang kondisi nyapsap yang dimiliki komunitasnya, selalu menjadi dasar mengapa sawah dan areal perkampungan selalu menghindari lokasi yang menjadi arah nyapsap tersebut. Oleh sebab itu, secara ideal sebuah perkampungan akan selalu dikembangkan di bagian hulu kelokan sungai yang berair deras. Ini dilakukan dengan tujuan agar perkampungan yang mereka kembangkan bisa tetap dipertahankan dari generasi ke generasi. Alternatif lain untuk menghindari nyapsap yang terjadi di kelokan sungai adalah dengan mengembangkan perkampungan menjauhi tepian sungai. 


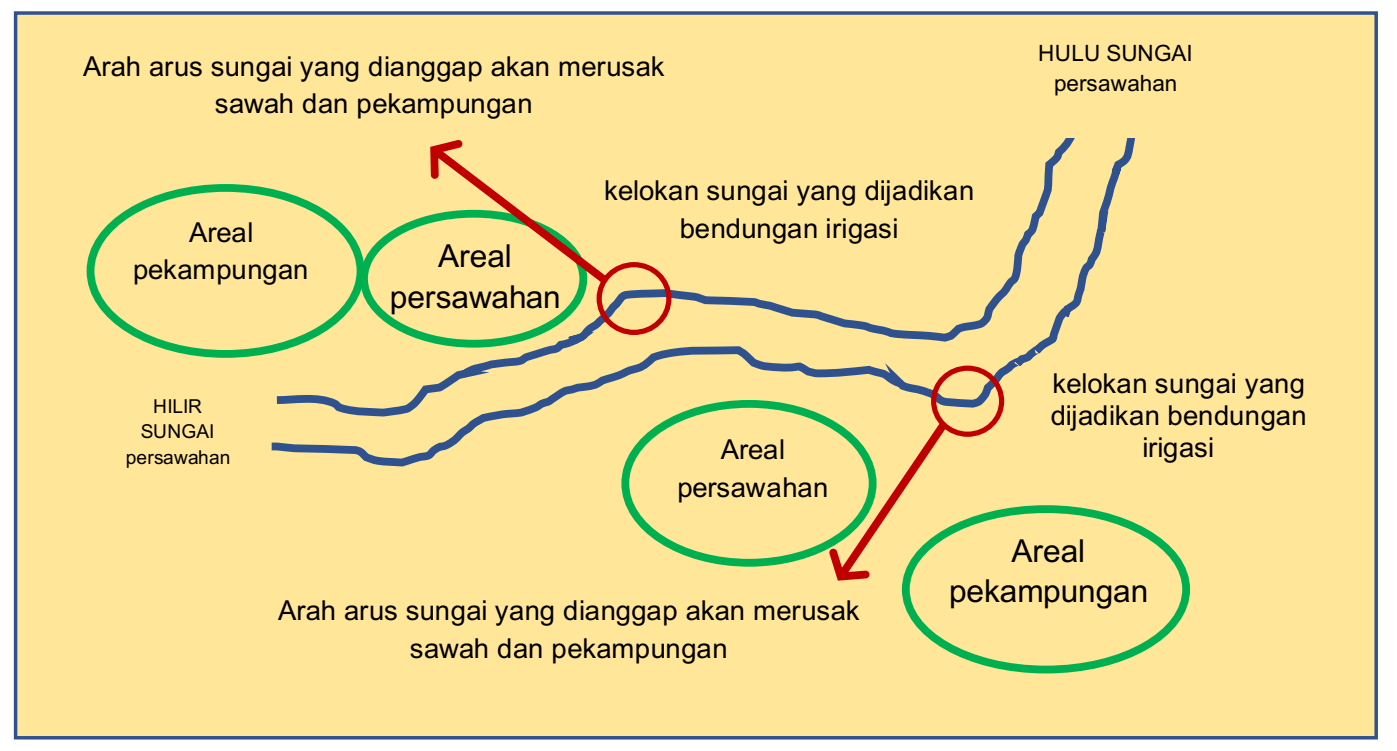

Gambar 5. Posisi Ideal Sawah dan Perkampungan Komunitas Melayu Ogan

Pengetahuan tentang sifat arus sungai yang ada di setiap kelokan sungai ini, cenderung akan menjadi dasar utama dalam menentukan penempatan areal persawahan dan perkampungan di setiap komunitas Melayu Ogan. Akan tetapi pengetahuan ini tidaklah berdiri sendiri, karena banyak bukti juga menunjukkan areal tepian sungai yang bukan menjadi arah arus kelokan sungai justru tidak dimanfaatkan oleh komunitasnya. Hal ini terkait dengan pengetahuan komunitasnya tentang jenis-jenis tanah dan pola pemanfaatnnya. Sebahagian besar lahan di permukiman komunitas Melayu Ogan adalah lahan yang terbentuk dari jenis tanah humus yang subur, yang mereka sebut dengan istilah tanah gunung. ${ }^{5}$ Dalam sistem kognitif komunitas Melayu Ogan, tanah gunung idealnya dimanfaatkan untuk areal perladangan, karena dianggap akan lebih mendukung perkembangan jenis tanaman ladang yang mereka kembangkan.

Jenis tanah gunung ini sebenarnya juga bisa dimanfaatkan untuk areal persawahan dan perkampungan. Akan tetapi pemanfaatan tanah gunung sebagai areal persawahan hanya akan dilakukan apabila di areal jenis tanah gunung tersebut memiliki sumber air yang bisa dijadikan irigasi untuk setiap areal sawah yang dimiliki. Tanah gunung ini juga bisa dimanfaatkan untuk areal perkampungan, atau areal peruntukan lain seperti kuburan, tetapi hanya akan dilakukan apabila tidak ada tempat lain yang memungkinkan untuk digunakan sebagai lokasi perkampungan atau pekuburan. Pertanian sebagai pola aktivitas kehidupan bagi komunitasnya, membuat pemanfaatan lahan tanah gunung untuk kebutuhan selain pertanian, dianggap akan merugikan potensi pertanian yang mereka miliki.

\footnotetext{
${ }^{5}$ Tanah gunung adalah sebutan bagi komunitas Melayu Ogan untuk jenis tanah humus yang ada di areal pengunungan. Jenis tanah ini cenderung berwarna coklat kekuning-kuningan, bersifat gembur (crumb), menggumpal dan terasa licin bila dipegang. Komunitas Melayu Ogan juga sering menyebut jenis tanah gunung ini dengan istilah tanah himbe (tanah di hutan rimba), karena jenis tanah ini banyak ditemukan di areal pegunungan yang masih memiliki hutan lebat.
} 
Pengetahuan komunitas Melayu Ogan lebih menempatkan areal perkampungan sebaiknya ada di lahan jenis tanah kasang. ${ }^{6}$ Oleh sebab itu, lahan dengan jenis tanah kasang yang relatif tidak terlalu jauh dari tepian sungai --- dan jauh dari kelokan sungai --dianggap sebagai lokasi paling ideal sebagai areal perkampungan. Sebaliknya, tanah kasang yang terlalu dekat dengan tepian sungai, akan dihindari sebagai lokasi pengembangan kampung, karena dianggap akan mudah terjadi longsong akibat gerusan arus sungai dari bawah tanah (nyapsap). Oleh sebab itu, pola umum yang di temukan di komunitas Melayu Ogan, perkampungan akan ditempatkan sedikit menjauhi tepian sungai, sementara lokasi antara perkampungan dan tepian sungai akan dimanfaatkan sebagai areal persawahan.

Sistem pengetahuan terkait dengan lingkungan sungai dan jenis tanah ini, akhirnya melahirkan pola tata ruang permukiman khas komunitas Melayu Ogan. Pola tata ruang permukiman ini, tidak saja terkait dengan dimana lokasi perladangan akan dilakukan, tetapi juga terkait dengan dimana perkampungan akan dibangun, dan dimana pula sebaiknya areal perkuburan dan sarana sosial akan dikembangkan. Sebagai sebuah kawasan, maka pola tata ruang permukiman tidak saja akan mengatur lokasi setiap komponen permukiman itu sendiri, tetapi juga sangat menentukan eksistensi perkampungan komunitasnya di kemudian hari. Pola umum yang ditemukan adalah permukiman akan dibuat di dekat sungai, karena terkait dengan kepentingan adanya sawah yang harus mereka pertahankan sebagai sumber pangan keluarga sehari-hari.

Sistem kognitif komunitas Melayu Ogan, memahami bahwa permukiman akan dibuat secara vertikal (tegak lurus) dengan aliran sungai. Lokasi yang ada di dekat sungai, lebih diorientasikan untuk areal persawahan, sementara lokasi yang menjauhi sungai lebih diorientasikan untuk areal perladangan. Lokasi perkampungan sendiri, akan ditempatkan menjauhi aliran sungai tetapi dekat dengan areal persawahan. Oleh sebab itu, ada dua pola tata ruang yang ditemukan, pertama, apabila sungai menjadi orientasi bersama antara dua kampung, maka tepian sungai akan menjadi areal sawah, diikuti dengan areal perkampungan, barulah di belakang perkampungan akan menjadi areal perladangan (lihat gambar 6, pola 1). Kedua, apabila sungai hanya menjadi orientasi satu kampung, maka tata ruang posisi perladangan akan berada di seberang sungai, sementara di belakang perkampungan akan menjadi lokasi kebun dan kuburan komunitasnya (lihat gambar 6, pola 2).

\footnotetext{
${ }^{6}$ Tanah kasang adalah sebutan komunitas Melayu Ogan untuk jenis tanah yang teksturnya sedikit kasar, keras, cenderung bercampur dengan pasir dan kerikil kecil, dan umumnya berwarna merah kekuningkuningan.
} 

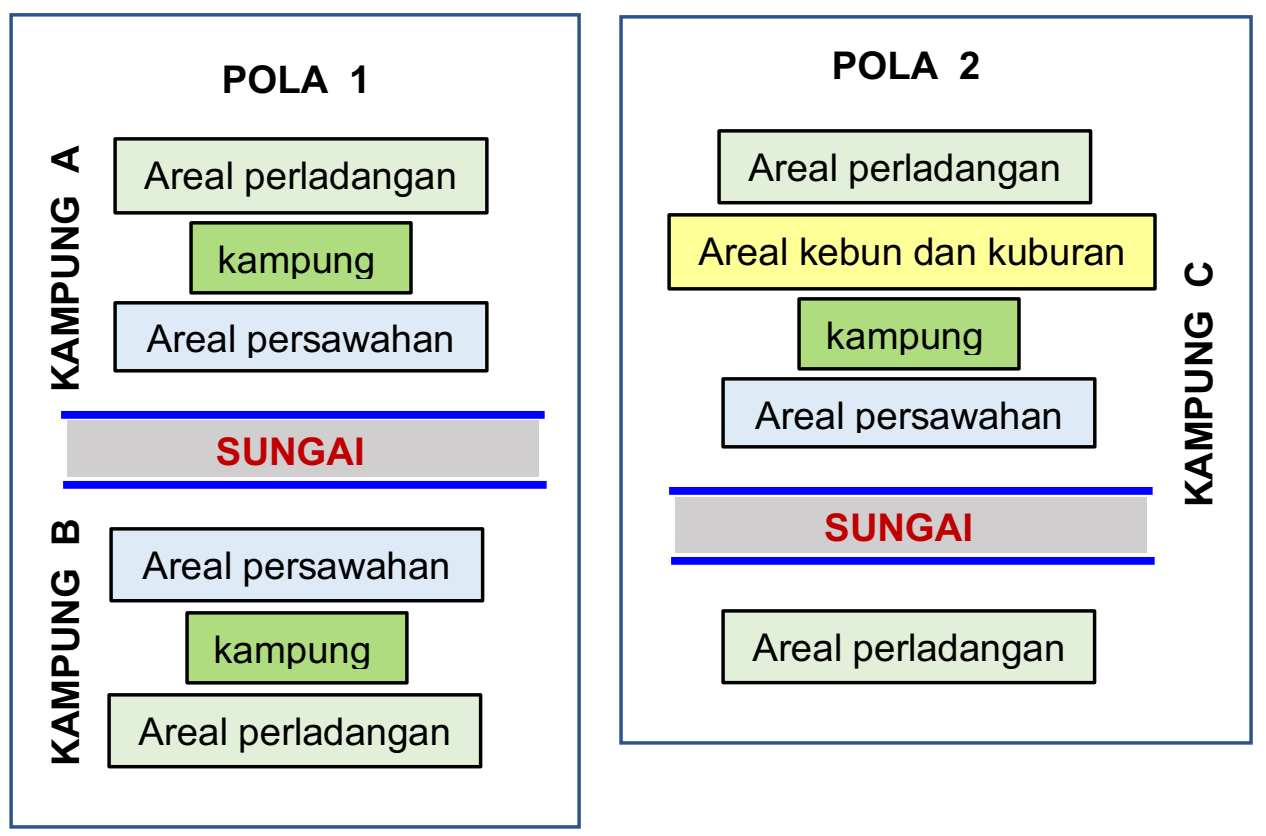

Gambar 6. Skema tata ruang permukiman komunitas Melayu Ogan

Keberadaan sungai sebagai elemen inti dalam pengembangan pola tata ruang permukiman, juga membawa implikasi terhadap lokasi dan posisi rumah-rumah sebagai tempat tinggal. Secara komunal, rumah-rumah akan dibangun secara berbaris sejajar dengan aliran sungai, dengan rumah keturunan pendiri kampung akan berada di lokasi yang paling mendekati sungai. Rumah-rumah pendiri kampung ini lah yang biasanya akan menjadi acuan utama dalam mendirikan rumah-rumah berikutnya. Ada dua pola penempatan rumah-rumah dalam tata ruang permukiman komunitas Melayu Ogan. Pola pertama adalah pola perkampungan mendekati tepian sungai (lihat Gambar 7, pola 1), dan pola kedua yaitu pola perkampungan yang menjauhi tepian sungai (lihat Gambar 7, pola 2).

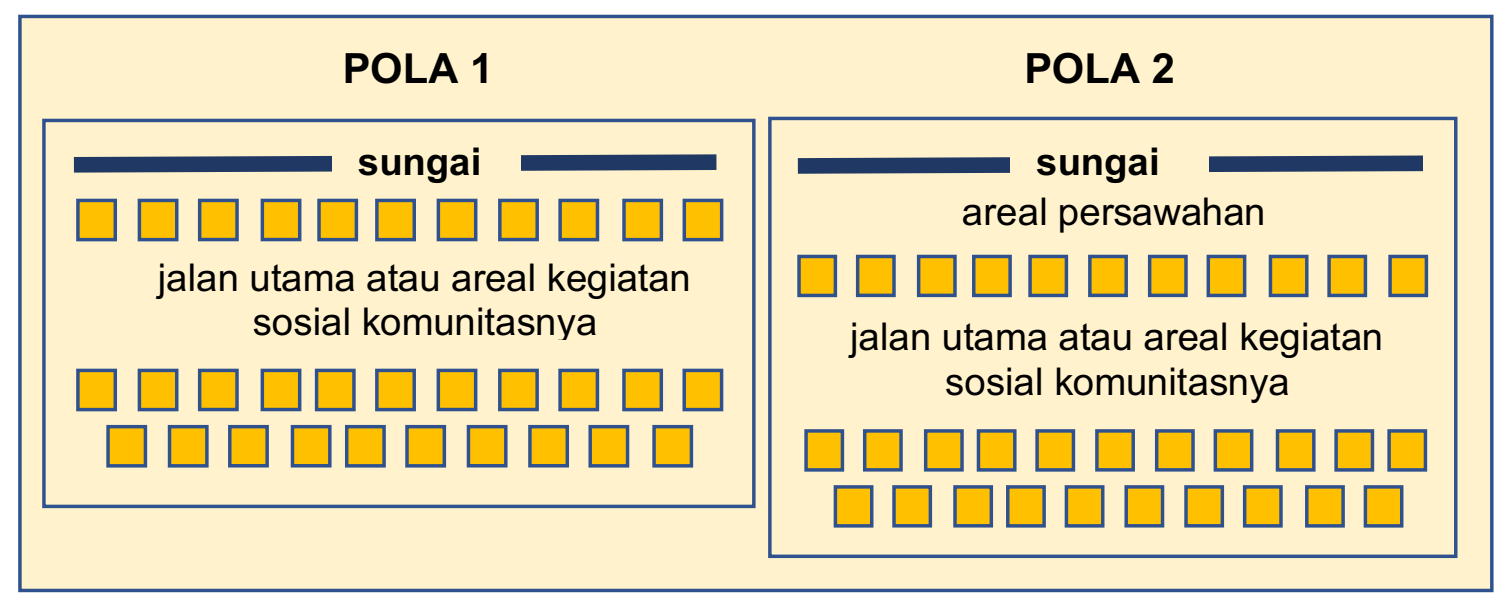

Gambar 7. Penempatan rumah di perkampungan tepian sungai (Pola 1) 
Tidak ada pembedaan secara signifikan antara pola pertama dan pola kedua, kecuali adanya areal persawahan yang ditempatkan antara sungai dengan bangunan rumah sebagai areal perkampungan. Bangunan utama (rumah para pendiri kampung), biasanya akan berada di lapisan pertama, yaitu barisan rumah yang lebih mendekati sungai. Pada lapisan kedua, biasanya berbentuk ruang terbuka, yang biasanya menjadi ruang sosial bagi aktivitas kehidupan komunitasnya. Pada beberapa kasus, ruang terbuka ini sekaligus menjadi jalan utama di perkampungan tersebut, yang menghubungkan antara kampung di bagian hulu dengan kampung di bagian hilir. Dengan adanya jalan utama ini, maka setiap rumah akan selalu dihadapkan ke arah jalan utama tersebut. Barulah pada lapisan terakhir, yaitu barisan rumah yang berseberangan dengan rumah-rumah, yang sekaligus sebagai ruang pengembangan perkampungan dikemudian hari.

Di perkampungan yang relatif mulai padat penduduknya, membuat banguan rumah akan terdiri dari beberapa baris. Apabila pola banguan rumah selalu dihadapkan ke jalan utama, maka penemptan setiap rumah akan dibuat bersilang sehingga rumah yang ada di barisan depan tidak secara langsung membelakangi rumah yang ada di barisan belakangnya. Ini berkaitan dengan posisi tundan (tempat pencucian dan buang air kecil) yang ada di belakang setiap rumah, karena bagian belakangnya cenderung akan menjadi tempat pembuangan limbah cair rumah tersebut. Rumah-rumah komunitas Melayu Ogan adalah rumah berbentuk panggung, sehingga buangan limbah cair dari tundan setiap rumah, relatif akan membanjiri depan rumah yang ada di belakangnya. Oleh sebab itu, alternatif lain yang sering ditemui, adalah dengan membuat bangunan rumah saling membelakangi satu sama lain, sehingga setiap depan rumah relatif terhindar dari buangan limbah cair keluarga tersebut. Apabila pola kedua ini dilakukan, maka biasanya pada bagian depan rumah di lapisan kedua ini akan dibuat sebuah gang kecil sebagai acuan dalam membangun rumah berikutnya.

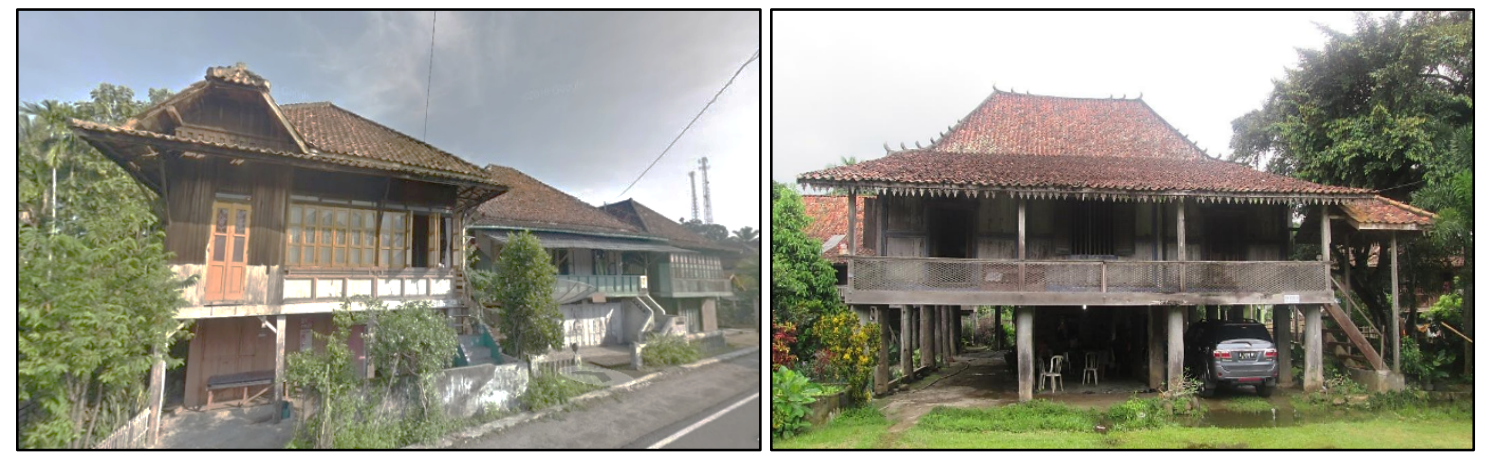

Gambar 8. Rumah bertiang tinggi komunitas Melayu Ogan

\section{Kesimpulan}

Sungai bagi komunitas Melayu Ogan adalah sentral dalah kehidupan dan budaya mereka, sehingga sangat mempengaruhi pola tata ruang permukiman yang mereka ciptakan. Bagi komunitas Melayu Ogan, bermukim di tepian sungai tidaklah bersifat arbitrer (suka-suka), tetapi merupakan bentuk perencanaan yang matang hasil pembacaan mereka terhadap lingkungan sungai dengan segala potensi yang dimilikinya. Salah satu aspek penting dalam pembacaan tersebut adanya pemahaman 
mereka akan pentingnya sawah sebagai sumber beras yang sangat mereka butuhkan dalam aktivitas sosialnya. Perkampungan selalu ditempatkan dekat areal persawahan karena aktivitas pertanian sawah dianggap membutuhkan perawatan intensif dari pemiliknya. Akibatnya perkampungan akan selalu mendekatai areal persawahan yang cenderung berada di tepian sunga.

Pola ini akhirnya melahirkan tata ruang tersendiri, dimana perkampungan sebagai tempat tinggal akan selalu berdekatan dengan areal persawahan, dan areal persawahan akan selalu berada di dekat sungai. Akan tetapi tidak semua areal dekat sungai akan dijadikan areal persawahan dan perkampungan, faktor kelokan sungai juga akan menjadi pertimbangan, karena kelokan sungai dipandang tidak saja bermanfaat bagi irigasi sawah mereka, tetapi juga dianggap berbahaya karena akan mengikis tepian sungai, yang dijadikan areal persawahan dan perkampungan mereka. Oleh sebab itu, untuk mempertahankan eksistensi sebuah permukiman, maka perkampungan akan selalu ditempatkan di hulu kelokan sungai, dan kalau perlu sedikit menjauhi kelokan sungai tersebut.

Hasil pembacaan komunitasnya terhadap lingkungan sungai ini akhirnya membawa implikasi terhadap pola tata ruang permukiman itu sendiri. Sebagai sebuah kawasan, maka permukiman akan selalu ditempatkan ditepian sungai dan dibuat secara vertikal (tegak lurus) dengan aliran sungai, dimana areal persawahan diposisikan di dekat aliran sungai, dan areal perladangan diposisikan menjauhi aliran sungai. Sementara areal perkampungan, akan ditempatkan dekat dengan areal persawahan, yang umumnya berada di antara areal persawahan dan areal perladangan. Pola ini umum ditemukan pada permukiman yang hanya menguasai lahan di satu sisi sungai saja, karena sisi sungai lainnya dikuasai oleh kampung yang lain juga dengan pola tat ruang yang sama. Sementara pada permukiman yang menguasai lahan di kedua sisi sungai, maka areal perladangan utama akan ditempatkan di seberang sungai, terpisah dengan areal persawahan dan perkampungan.

Ini menunjukkan bahwa sungai bagi suatu komunitas, tidak saja akan dipahami secara fungsional, tetapi juga mengandung makna secara budaya. Sungai akhirnya juga menjadi media yang tepat untuk membaca keberadaan dan identitas suatu kelompok atau komunitas di suatu wilayah tertentu. Hal ini disebabkan karena sungai tidak saja membawa implikasi pada pola pertanian yang berkembang dan dikembangkan di suatu wilayah, tetapi juga membawa implikasi pada pola tata ruang yang dihasilkan. Oleh sebab itu, bermukim di tepian sungai harus dipandang sebagai bentuk identitas sekaligus penguatan budaya dalam kehidupan suatu komunitas.

\section{Referensi}

Ahimsa-Putra, H.S. (1997). “Arkeologi Permukiman. Asal Mula dan Perkembangannya” in Humaniora (5): 15-25.

Ahimsa-Putra, H.S. (1998). “Beberapa Paradigma Diakronis dalam Arkeologi Pemukiman" in Humaniora (7): 24-34.

Arifin, Z. (1998). Talang: Classification System and Pattern of Adaptation of Ogan Tribes in the Process of Forming and Structuring New Settlements. Thesis Magister Antropologi in Gadjah Mada University, Yogakarta 
Arifin, Z. (2015). Kebudayaan dan Warisan Tak Benda di Provinsi Sumatera Selatan. Disampaikan dalam acara "Rapat Teknis Pelestarian Nilai Budaya dalam Rangka Penetapan Warisan Budaya Tak Benda (WBTB) Provinsi Sumatera Barat, Bengkulu dan Sumatera Selatan." Pada tanggal 14-16 Juni 2015. Padang: Kemendikbud

Arifin, Z. (2018). Tunggu Tubang. Pattern of Power and Resource Control at Semende Community, South Sumatera. Padang: Rumah Kayu Pustaka Utama.

BPS. (2019). Kabupaten Ogan Ilir dalam Angka. Indralaya: Badan Pusat Statistik.

BPS. (2019). Kabupaten Ogan Komering Ulu dalam Angka. Baturaja: Badan Pusat Statistik.

Boster, J.S. (2012). "Cognitive Anthropology Is a Cognitive Science", in Topics in Cognitive Science (4): 372-378.

Desfor, G., Keil, R. (2000). "Every River Tells a Story: the Don River (Toronto) and The Los Angeles River (Los Angeles) as Articulating Landscapes" in Journal of Environmental Policy \& Planning 2(1): 5-23.

Guilland, D. (2006). Menyelusuri Sungai, Merunut Waktu. Penelitian Arkeologi di Sumatera Selatan. Jakarta: IRD-Enrique Indonesia.

Hanafiah, D. (1985). Melayu Jawa: Citra Budaya dan Sejarah Palembang. Jakarta: Penerbit PT. Raja Grafindo Persada.

Havrelock, R. (2007). "My Home is Over Jordan: River as Border in Israeli and Palestinian National Mythology" in National Identity 9(2): 105-126.

Intan, M.F.S. (2016). "Banyu Biru: Traces of Ancient River in Wetland", presented at Seminar EHPA 2016, di Cirebon (25-29 October 2016).

Kasmin, Y. (2017). “Arkeologi Permukiman Situs Pongko, Kabupaten Bone, Sulawesi Selatan" in Jurnal Walennae 15(1): 43-58.

Keane, W. (2015). Why Cognitive Anthropology Needs to Understand Social Interaction and Its Mediation, in Social Anthropology 23(2):192-193.

Kumar, D. (2017). "River Ganges - Historical, Cultural and Socio-Economic Attributes" in Aquatic Ecosystem Health \& Management 20(1-2): 8-20.

Langub, J., Noboru, I. (2016). Community, River and Basin: Watersheds in Northern Sarawak as a Social Linkage" in V.T. King et al. (eds.) Borneo Studies in History, Society and Culture. Singapore: Institute of Asian Studies. (pp.465-384).

Ludvik, C. (2007). Sarasvatī Riverine Goddess of Knowledge. Leiden: Koninklijke Brill NV.

Melalatoa, M.J. (2015). Ensiklopedia Suku Bangsa di Indonesia. Jakarta: Kementrian Pendidikan dan Kebudayaan.

Pahrudin. (2010). “Menyingkap Situs Koto Rayo, Pemukiman Kuno di Tepi Sungai Tabir Jambi". Jurnal Unisia 33(73): 86-94.

Paine, L. (2018). "River Cultures in World History - Rescuing a Neglected Resource" in Fudan Journal of the Humanities and Social Sciences (online first article). (pp.1-16).

Peacock, J.L., Kirsch, A.T. (1970). The Human Directian. An Evolutionary Appraach to Social and Cultural Anthropology. New York: Appleton Century-Crofts.

Prasetyo, S.E. (2012). "Potential of Archeological Area of Flow Sungai Kikim District, Lahat District, South Sumatera" in Jurnal Papua 4(1): 51-64.

Rice, G., Urban, M.A. (2007). "Where is River City, USA? Measuring Community Attachment to the Mississippi and Missouri Rivers". Journal of Cultural Geography 24(1): 1-35.

Ririmase, M.N.R. (2007). “Ruang Sebagai Wahana Makna. Aspek Simbolik Pola tata ruang dalam Rekayasa Pemukiman Kuno di Maluka". Jurnal Kapala Arkeologi 3(5): 72-106.

Stahlberg, S., Svanberg, I. (2017). “When Is a Foraging Society? The Loplik in the Tarim Basin" in Victoria Reyes-García and Aili Pyhala (eds)Hunter-Gatherers in a Changing World. Switzerland: Springer International Publishing (pp.21-37) 
Susanto, N.N. (2016). "Archaeological Remains and Traditions on The Barito Drainage Basin, in Barito Selatan and Barito Timur Regencies, Central Kalimantan Province". Kindai Etam.Jurnal Penelitian Arkeologi 2(1): 51-68.

Tyler, S.A. (1969). "Introduction" in Stephen A. Tyler (eds). Cognitive Anthropology. New York: Holt, Rinehart and Winston, Inc. (pp.1-23).

Wassmann, J., Bender, A. (2015). "Cognitive Anthropology", in James D.Wright (eds) International Encyclopedia of the Social \& Behavioral Sciences (Second Edition). Orlando: University of Central Florida. (pp.16-22). 